\title{
A propósito de Pós-graduAÇão em LITERATURA PORTUGUESA
}

\author{
Intervenção de NADIA FERREIRA MENDONÇA \\ (Professora da Universidade Estadual do Rio de Janeiro)
}

Agradecemos aos organizadores desse seminário a subida honra de estar ao lado do amigo e mestre Leodegário A. Azevedo Filho.

Desejariamos dizer que, concordando en linhas gerais com a excelente palestra do professor Leodegário, apenas acrescentaríamos a título de enrlquecimento duas questōes.

1." questio: 0 ensino de literatura em geral e especificamente literatura portuguesa nāo devia nunca esquecer de que a llteratura é um objeto cuja loitura depende de uma Teoria do Discurso.

2.^ questáo: Se o curso de Pós-graduação tem como meta o desenvolvimento crítico reflexivo do ensino de literatura, c, tormndo como base a proposição anterior, a orientacãa teórica desso cursa não deve partir da dicotomia radical entre literaturas nacionais. Isto porque apesar de possuirem contextos diferentes, por serem discurso literárlo possuem egtruturas analogas. Concluindo, nensamos que se deve evitar que os cursos de p6s-graduação estruturem-se de forma a provocarem no ensino das literaturas, e especificamente, da literatura portuguesa a departamentalização estanque de suas unidades reflexivas. 